\title{
Description of a New Species of Sphincteristomum from Sparid Fishies of the Algerian Coast (Western Mediterranean)
}

\author{
Sihem Abid-Kachour*, Salim Mouffok, Zitouni Boutiba \\ Laboratoire Réseau de Surveillance Environnementale, Département de Biologie, Université d’Oran, Oran, Algérie. \\ Email: *Sihemabid@yahoo.fr
}

Received June $6^{\text {th }}$, 2013; revised July $9^{\text {th }}, 2013$; accepted August $11^{\text {th }}, 2013$

Copyright (c) 2013 Sihem Abid-Kachour et al. This is an open access article distributed under the Creative Commons Attribution License, which permits unrestricted use, distribution, and reproduction in any medium, provided the original work is properly cited.

\begin{abstract}
The objectif in the present study is description of a new species of Sphincteristomum Oshmarin, Mamaev \& Parukhin 1961, named Sphincteristomum mediterraneae, which is described in Oran bay, Algeria. It parasitizes the intestine of naturally infected Pagellus erythrinus, Teleostei, Sparidae. The Pagellus erythrinus is in important food fish in the Mediterranean. This genus belongs to the family Apocreadiidae, sub family Schistorchiinae, characterized by an obvious oral muscular sphincter, into a large oral sucker, a disc-shaped acetabulum under the intestinal bifurcation, an ocular pigment scattered in the forebody, a sequence ovary and two testes in tandem and a I-shaped excretory bladder. In the new species, the digestive apparatus displays a hexagonal peculiar aperture, followed by a longitudinal slit, a waved pharynx, two long and broad caeca, with a thick internal wall of endothelial cells. Each caecum has a sub terminal anus. The female genital apparatus displays a transversally elongated ovary, under the acetabulum. On the side of the ovary, there is a small Mehlis gland. Under the ovary, there are two transverse converging vitelloducts. Lateral and extracaecal vitelline follicles, are spread near the caeca. They converge in the hindbody. The relatively short uterus is preovarian, mainly. It contains few large yellow eggs. Its distal part is creased transversally, just before ending in genital atrium. The male genital apparatus shows two lobed heart-shaped testes, post ovarian, in tandem. From the anterior edge of each testis, two spermiducts climb up and converge into a naked, curved or sinuous seminal vesicle, followed by a short prostate surrounded by few prostatic cells, and a narrow ejaculatory duct, opening in genital atrium. The genital pore is close to the acetabulum and the intestinal bifurcation. No cirrus pouch. The excretory system shows a relatively short tubular I-shaped bladder, reaching the inferior level of the second testis. Two thin excretory arms are seen until the forebody of the worms. The terminal excretory pore is closed by a small sphincter. In the same P. eryrthrinus, immature worms devoid of genitalia, young worms with genitalia devoid of eggs and ovigerous worms, live together with senile specimens. These last ones show still, oral sucker, diffuse vitelline follicles and very small and scattered ocular pigment.
\end{abstract}

Keywords: Digenea; Sphincteristomum Oshmarin; Oran bay; Pagellus erythrinus; Teleostei

\section{Introduction}

Digenean parasites of Apocreadiidae family from fish of the Western Mediterranean have received a considerable attention in recent year [1]. Pagellus erythrinus, in Mediterranée westerner and in particular in Algeria few works exists on the parasitofaune of this marine host, this deficiency aroused our interets in investigated by advantage. This Teleostei fish takes a preponderant places as link in the throphodynamic chain and may be used as

${ }^{*}$ Corresponding author. an intermediary or definitive host into the cycle of many Digenea parasite. They are caught in the Oran bay, Algeria (Figure 1), and dissected, for helminth investigation. These fishes are parasitized largely by a small new species of Digenean, dwelling in intestine of their hosts. The species is described in the present work.

\section{Materials and Methods}

The Digeneans recovered from intestine of $P$. erythrinus are set into alcohol of 70 volumes, stained some minutes in boracic Carmin of Grenacher, dedifferentiated in 


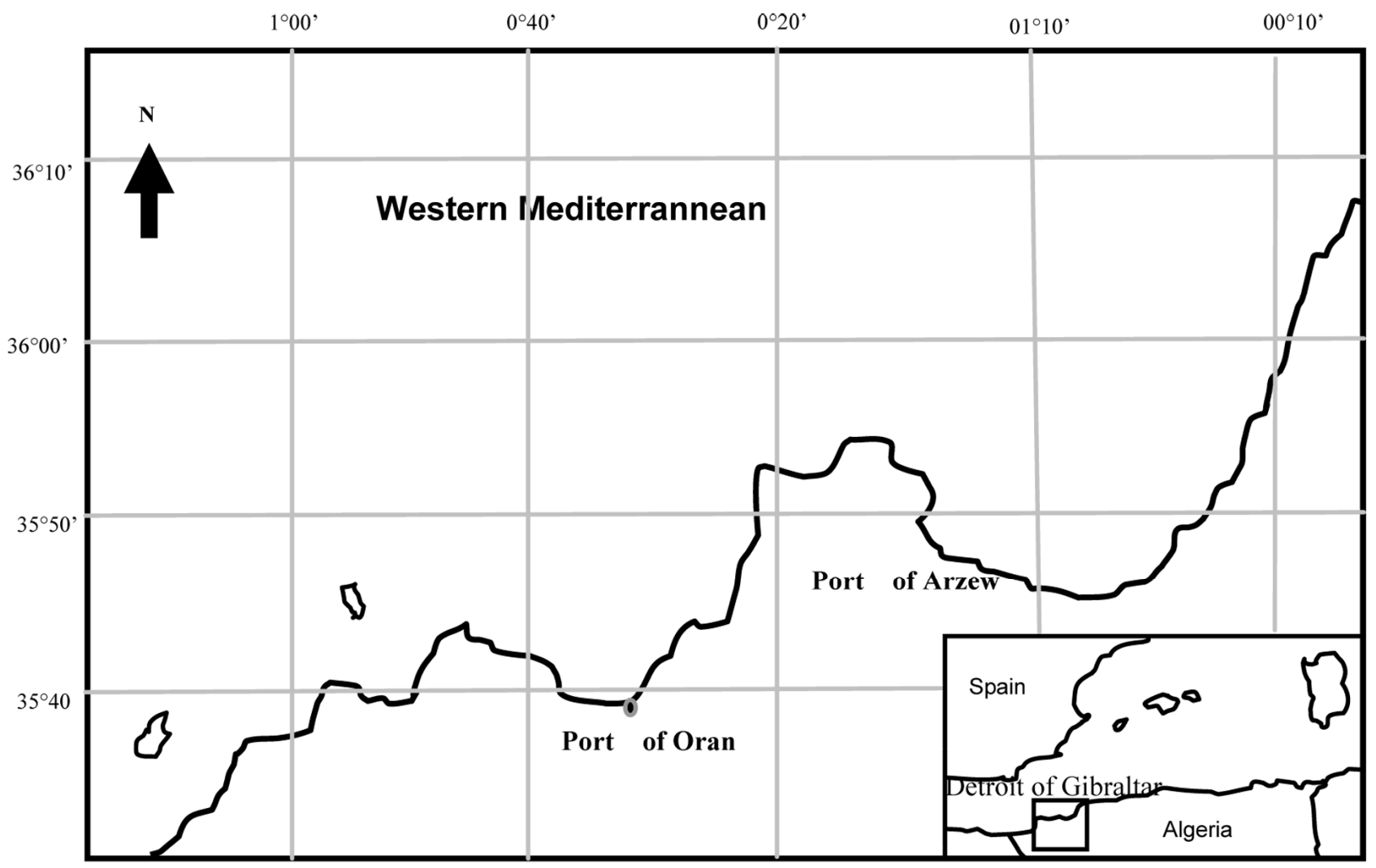

Figure 1. Map of area studies.

chlorhydric acid, dehydrated in successive baths of alcohol of 70, 85, 95 volumes, then in two baths of absolute ethanol of 100 volumes. They are cleared in Eugenol and mounted in Canada balsam. They are drawn with the camera lucida of an Olympus microscope.

\section{Results}

Fifty $P$. erythrinus are dissected between October 2010 and June 2011. Seasonal variations in the presence of Digeneans and variations linked with the size of the hosts are noted. For the recovered new species, the higher period occurs in spring, between April and June 2011, in $75 \%$ of fishes measuring 13 to 19 centimetres, and in $30 \%$ to $45 \%$ of fishes measuring 7 to 12 centimetres.

A convenient period is observed in autumn between October and December 2010 and during the last part of winter, in February-March 2011 in 30\% of fishes. No parasite in January 2011. No dissection in July and August

Description of our new species (Figures 2-4). It is based on observations of seven specimens, showing various stages of development, from which one immature worm. One immature worm devoid of genital apparatus, displays a very large oral sucker, a small acetabulum, a digestive apparatus, and an excretory apparatus, only. Juvenile worms with moreover, a genital apparatus devoid of egg. Ovigerous worms (Table 1), with all the apparatus and eggs. Ovigerous worms. Details, lobes in oral sucker, level of ovary, Melhis gland, Laurer's canal, excretory anterior arms.

Main distinctive features. Very large lobed oral ucker, provided with an inner powerful muscular sphincter, with an outer circular and longitudinal musculature. Mouth opening in an irregular hexagonal aperture flowed by a narrow slit. Small acetabulum weakly muscular. Three genitalia in tandem, in the hindbody: an ovary transversally elongated, followed by two testes lobed heartshaped. Extracaecal vitelline follicles, converging in the hindbody.

Sinuous pear-shaped seminal vesicle, near the cetabulum, slightly globular short prostate, surrounded by few prostatic cells, narrow ejaculatory duct. No cirrus pouch.

Creased distal uterus. Spherical genital atrium. Caeca with subterminal ani. Short excretory bladder I-shaped (Figure 2(b)).

Body. About twice longer than broad. The average length $\times$ width, measured on seven specimens, is $0.62 \times$ 0.34 millimetre. Body coat smooth, without spine. Antero-dorso-lateral eye pigment, under the oral sucker. Undulating body side edges.

Suckers. Oral sucker very large (Figure 2(a)), with a diameter of about 0.18 millimetre. It includes, in the in- 


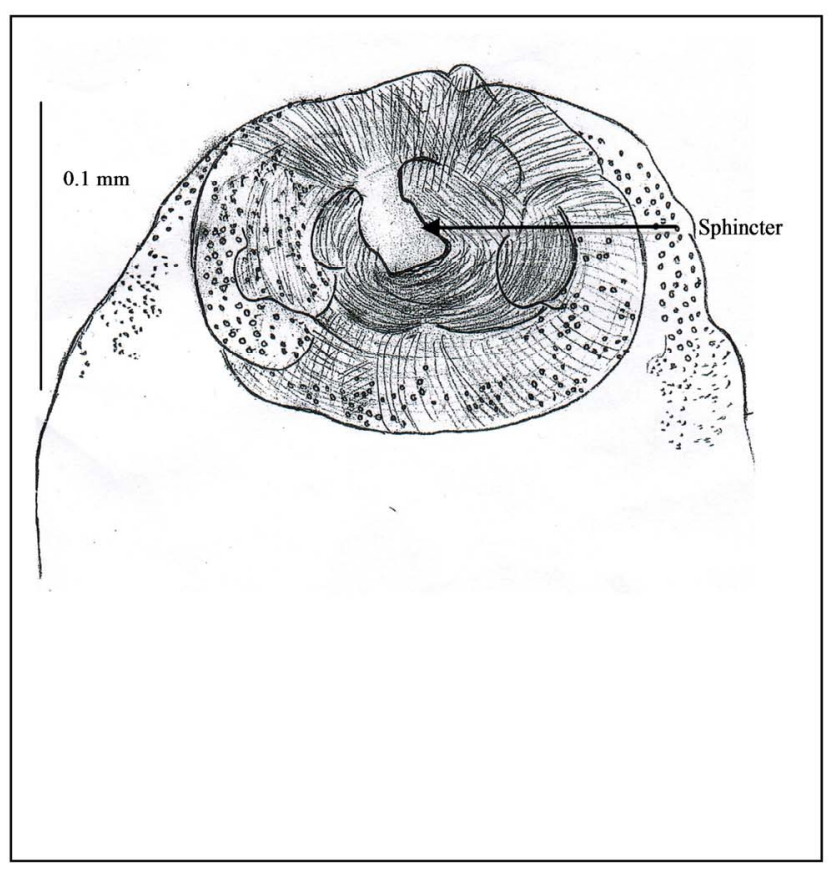

(a)

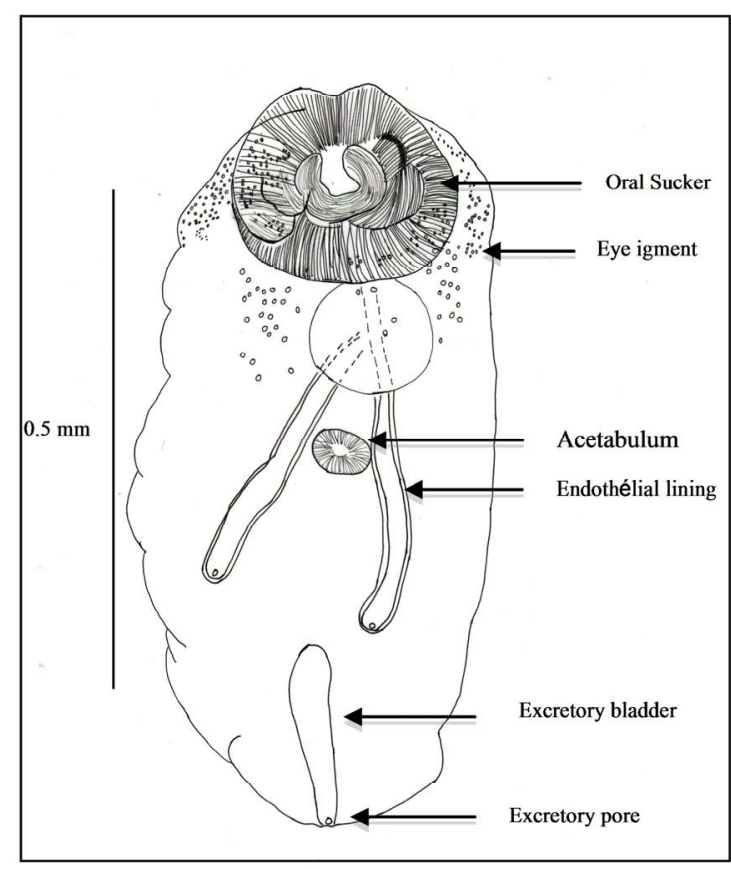

(b)

Figure 2. Immature worm. (a) Oral sucker and sphincter; (b) General view.

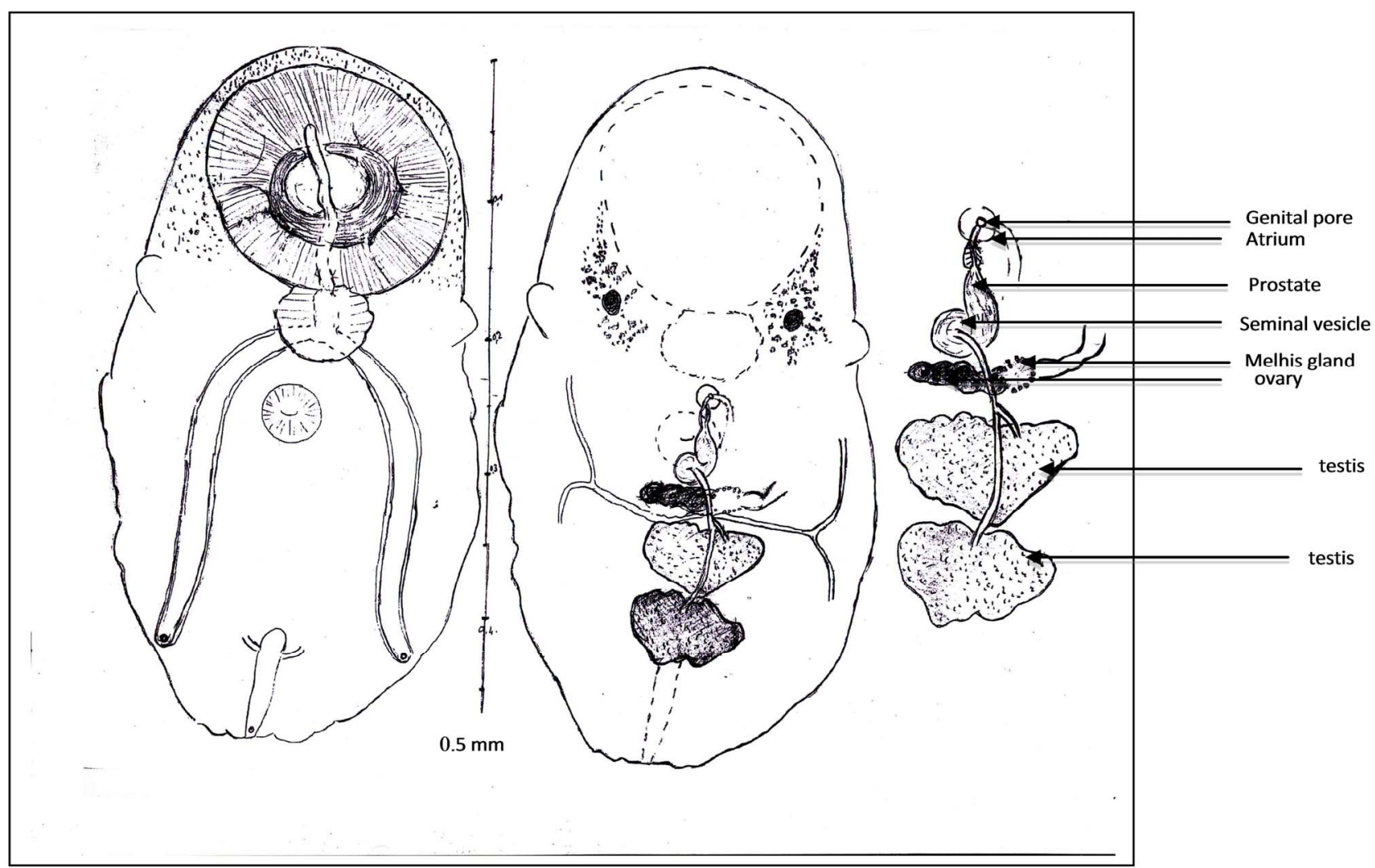

(a)

(b)

(c)

Figure 3. Juvenile worm (a); General view. Oral sucker and sphincter. Acetabulum. Digestive apparatus, buccal slit, pharynx, caeca, endothelial lining, ani. Eye pigment. Ovary, Melhis gland, vitelloducts. Testes, spermiducts. Excretory bladder, ending of excretory arms. Excretory pore, Scale (b); Terminal genitalia. Seminal vesicle, prostate, prostatic cells. Ejaculatory duct. Proximal uterus. Distal uterus. Atrium. Genital pore, Scale (c). 


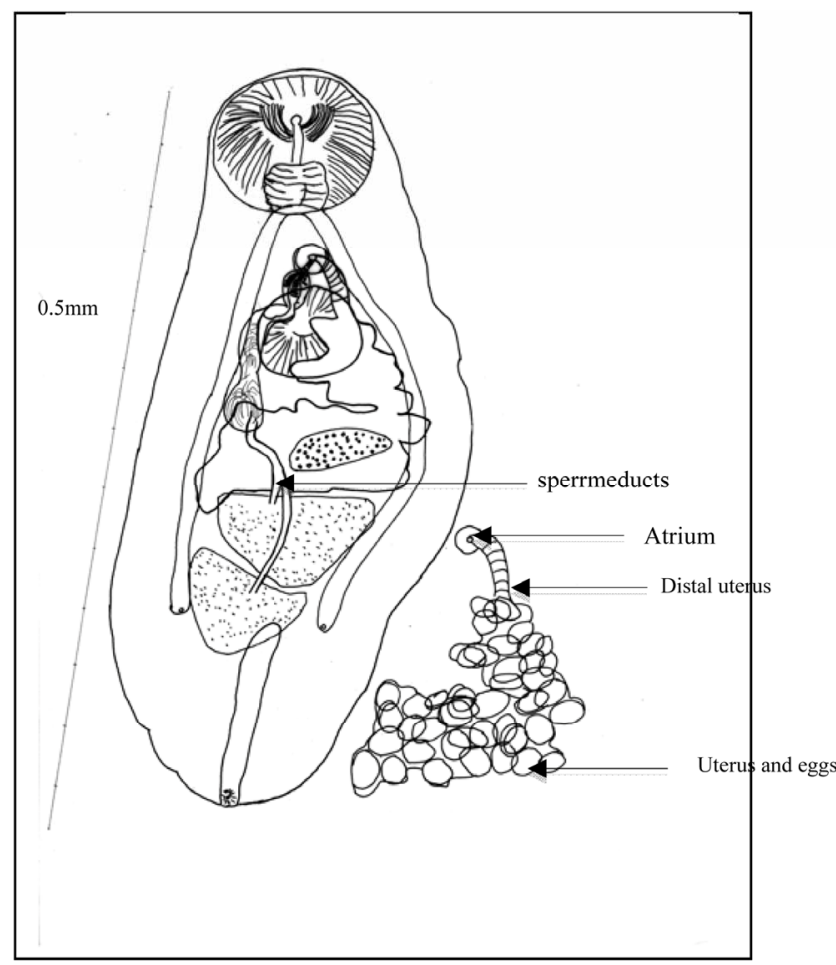

(a)

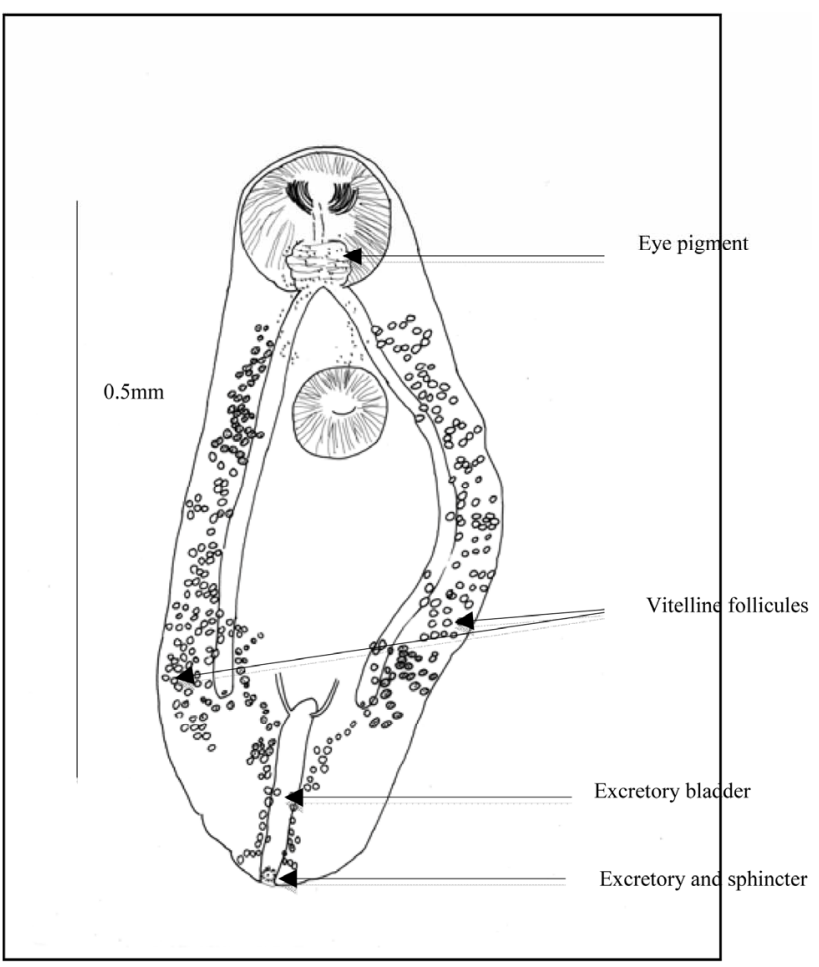

(b)

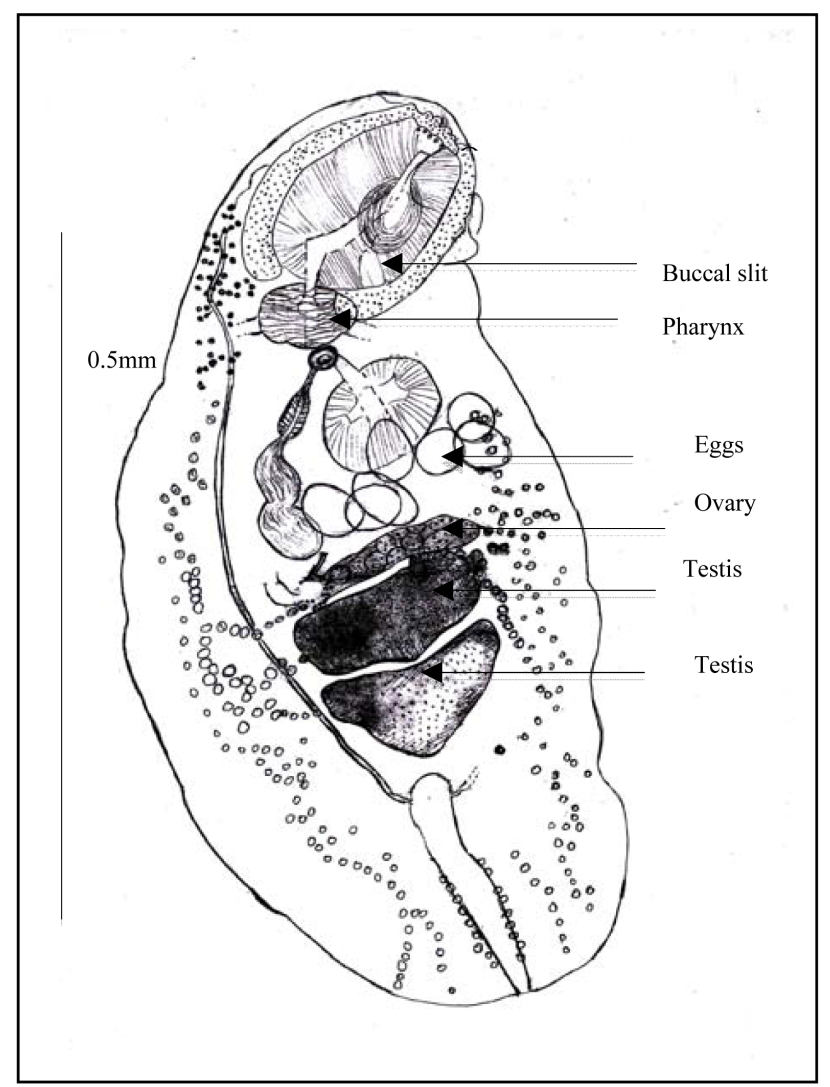

(c)

Figure 4. Ovigerous worm (a) General view. Caeca. Uterine outline. spermiducts. Seminal vesicle. Prostate. prostatic cells. Ejaculatory duct. Distal uterus. Atrium. Genital pore. Uterus and eggs; (b) Scattered eye pigment. Vitelline follicles. Excretory bladder. ending of excretory arms. Excretory pore and sphincter; (c) Buccal slit. Pharynx. Testis. Eggs. Ovary. 
Table 1. Comparaison of Sénile and ovigerous worms in Pagellus erythrinus host.

\begin{tabular}{|c|c|}
\hline Senile worms & Ovigerous worms \\
\hline $\begin{array}{l}\text { Present in intestine of } P \text {. erythrinus. They are not very different } \\
\text { from younger ones. } \\
\text { Average body size: } 0.52 \times 0.28 \mathrm{~mm} \text {. Compacted body, devoid of } \\
\text { lateral undulated edges, and tapered extremities. } \\
\text { Suckers. Oral sucker with oral sphincter, losing its muscles. } \\
\text { Disappearing acetabulum. } \\
\text { Digestive apparatus. Faded outline of the pharynx. Flattened } \\
\text { caeca. } \\
\text { Genital male apparatus. Testes with distended edges and empty } \\
\text { cellular contents. Fading outline of seminal vesicle, prostate and } \\
\text { ejaculatory duct. } \\
\text { Genital female apparatus. Persistent ovary. Uterine outline } \\
\text { disappearing. Sometimes, persistence of few eggs. Persistent } \\
\text { diffuse vitelline follicles. } \\
\text { Hermaphroditic terminal genitalia. Persistent genital atrium. } \\
\text { These senescent worms are mobile, alive. }\end{array}$ & $\begin{array}{l}\text { Present in intestine of P. erythrinus. } \\
\text { Very large lobed oral sucker, provided with an inner powerful muscular } \\
\text { sphincter. } \\
\text { Body. About twice longer than broad. The average length x width, measured on } \\
\text { seven specimens, is } 0.62 \times 0.34 \text { millimetre. } \\
\text { Suckers. Oral sucker very large, with a it includes, in the inner part around the } \\
\text { mouth, a lobed muscular sphincter. Acetabulum flat, disc-shaped, with diameter } \\
\text { about twice smaller than the oral sucker. } \\
\text { Digestive apparatus. Buccal aperture followed by a long slit, into the oral } \\
\text { sucker. Pharynx with a waved edge. Two long caeca, provided with a high } \\
\text { endothelial lining. } \\
\text { Genital male apparatus. Two testes tandem, in the posterior third of the ody. } \\
\text { They are, median, heart-shaped, post-ovarian. Genital female apparatus. It } \\
\text { includes a median, post acetabu lar, pretesticular transvrsally elongated ovary in } \\
\text { its neighbourhood, a small Mehlis gland, a thin Laurer' canal, two transverse } \\
\text { vitelloducts, a short, pre-ovarian thin-walled uterus. Hermaphroditic terminal } \\
\text { genitalia show a naked, arched or sinuous seminal vesicle, a short prostate, with } \\
\text { few prostatic cells. and a narrow ejaculatory duct. }\end{array}$ \\
\hline
\end{tabular}

ner part around the mouth, a lobed muscular sphincter. And in the outer part, circular and longitudinal muscles, and numerous gland like cells.

Acetabulum flat, disc-shaped, with diameter about twice smaller than the oral sucker.

Ocular pigment. In immature worms, two dark eyes are conspicuous dorsally, surrounded by broad grains. In ovigerous worms, the ocular pigment is scattered, pulverized in minute grains (Figure 2(b)).

Digestive apparatus. Buccal aperture followed by a long slit, into the oral sucker. Pharynx with a waved edge. Two long caeca, provided with a high endothelial lining (Figure 3(b)), on their inner wall. Each one opens by a subterminal anus.

Genital male apparatus. Two testes tandem (Figure 3(c)), in the posterior third of the body. They are, median, heart-shaped, post-ovarian. The first testis measures, in its greatest dimension, $0.10 \mathrm{~mm}(>0.07,<0.12)$. The second one measures, in its largest dimension, $0.15 \mathrm{~mm}$ $(>0.08,<0.24)$. They can overlap slightly in old specimens.

The terminal genitalia show a naked, arched or sinuous seminal vesicle, a short prostate, with few prostatic cells and a narrow ejaculatory duct. Seminal vesicle bypasses part of the acetabulum. Ejaculatory duct ends in genital atrium. No cirrus pouch.

Genital female apparatus. It includes a median, post acetabular, pretesticular transversally elongated ovary. It measures, in its greatest dimension, $0.10 \mathrm{~mm}(>0.06,<0.14)$. In its neighbourhood, a small Mehlis gland, a thin Laurer' canal, two transverse vitelloducts, a short, pre-ovarian thin-walled uterus. In juvenile specimens, uterus is without egg. In older specimens, it contains a relatively small number of eggs ( 2 or 4 , or 6 , or 10 , and only once, 40 eggs). These eggs are light yellow coloured, thin-shelled, large. Average size, $0.030 \times 0.024 \mathrm{~mm}$. The distal part of the uterus transversally creased, ends in genital atrium, just before the median genital pore, near the intestinal bifurcation. Vitelline follicles are spread in two narrow bands, along the outer edge of the caeca. They converge in posterior area of the body.

Excretory apparatus. The urinary bladder is short, I-shaped. It reaches the lower level of the second testis. Its anterior part receives two thin excretory ducts coming from the forebody. The subterminal excretory pore is closed by a small sphincter.

Senile worms (Table 1). Besides the typical stages, senile worms are present, in intestine of $P$. erythrinus. hey are not very different from younger ones. But they appear altered. They are described briefly, underneath, without drawing.

Average body size: $0.52 \times 0.28 \mathrm{~mm}$. Compacted body, devoid of lateral undulated edges, and tapered extremities.

Suckers. Oral sucker with oral sphincter, losing its muscles. Disappearing acetabulum.

Digestive apparatus. Faded outline of the pharynx. Flattened caeca.

Genital male apparatus. Testes with distended edges and empty cellular contents. Fading outline of seminal vesicle, prostate and ejaculatory duct.

Genital female apparatus. Persistent ovary. Uterine outline disappearing. Sometimes, persistence of few eggs. Persistent diffuse vitelline follicles.

Hermaphroditic terminal genitalia. Persistent genital atrium.

These senescent worms are mobile, alive.

Identification of our species to a family and subfamily. Our batches of juvenile and ovigerous worms display several characteristics observed in Apocreadiidae Skrjabin 1942, Schistorchiinae [2] and Postporinae, [3], which khave been reviewed by Cribb in Jones et al. 
(2005) [1].

As Schistorchiinae, they have an oral sphincter in a large oral sucker. A small acetabulum near the intestinal bifurcation. Eye pigment in antero-dorsal region. Terminal male genitalia devoid of cirrus pouch, showing; a sinuous seminal vesicle, a prostate, and a thin ejaculatory duct. Genitalia including ovary and testes tandem.

Yet, in our species, the gonads are in the hindbody.

Schistorchiinae includes five genera, from which, Sphincteristomum [4] (Figure 4(c)), and Sphincterostoma [5] (Figure 4(b)), with two testes in forebody and Schistorchis Lühe, 1906, Megacreadium Nagaty, 1956 Neomegacreadium [6], with nine to thirteen testes, in one or two files.

As Postporinae, juvenile and ovigerous worms from our species, have an ovary and two testes tandem in the hindbody.

The Postporinae subfamily includes one genus with two species Postporus epinepheli $[7,8]$ and P. mycteropercae [7,8] (Figure 4(a)). This genus shows, anterior eye pigment, an ovary and two testes tandem in hindbody, lateral extra caecal vitellus as our species. It differs from our species by its oral sucker devoid of sphincter, its blind caeca, its genital pore posterior to acetabulum, its very long excretory bladder reaching the pharyngeal level, in the first species and the intestinal bifurcation, in the second species

Among the Apocreadiidae, our new species appears closely related with genera Sphincteristomum, Sphincterostoma, Schistorchiinae, and Postporus, Postporinae (Figure 4).

Comparison of our species with Sphincteristomum. The genus admits two species:

The type-species S. acollum [4], described in Balistidae fish Abalistes stellaris off the north coast of Vietnam and S. aniferum [9] (syn. Lobatotrema aniferum) from a Balistidae off Fiji island between New Caledonia and New Zealand.

Similarities. Like S. acollum, our species has an obvious sphincter in the oral sucker, a transversally elongated ovary, two lobed heart-shaped testes, a bilateral ondulating edge of the body and two terminal caeca open in ani.

Like $S$. aniferum, our species has a peculiar large oral sucker with minute longitudinal and transverse muscles, caeca with an inner endothelial lining and opening in ani.

Differences. S. acollum and S. aniferum have gonads in anterior or middle region of the body. Our species has gonads in posterior region.

S. acollum and S. aniferum have intracaecal and extracaecal vitelline follicles. Our species has, mainly, two narrow extra caecal bands of vitelline follicles.

Comparison with Sphincterostoma (Table 2). The genus admits one species:

The type-species S. branchiostegi [5], described in Branchiostegus japonicus off the west coast of Japan. The second one is Sphincterostoma sp [9] from a Balistidae, probable Balistapus, off Fiji island.

Similarities. Like S. branchiostegi, our species is present in intestine of its host, at different stages of development, according to Yamaguti, 1937 [5].

Differences. The two species of Sphincterostoma have a lateral and ovoid ovary. Our species has a median transversally elongated ovary. In S. branchiostegi, the oral sphincter surmounts the oral sucker. The I-shaped excretory bladder is long and reaches the anterior edge of the first testis. Location of Sphincterostoma sp. Manter, ingills of the host.

No mention or drawing of endothelial lining in caeca of the two Sphincterostoma. Our species has an endothelial lining in caeca, at least in juvenile and ovigerous specimens

Comparison with Postporus (Table 2). The genus admits two species $P$. epinepheli [8], type-species, and $P$. mycteropercae [8], described respectively in Epinephelus morio and Mycteroperca venenosa, Serranidae off the Atlantic American coast of Florida.

Similarities. Eye pigment. Gonads in the hindbody. Vitelline follicles mainly extracaecal.

Differences. Spiny body. Absence of oral sphincter. Ovoid ovary. Post acetabular terminal male genitalia. Very long I-shaped excretory bladder.

Table 2. The differences morphological of genus in Apocreadiidae family.

\begin{tabular}{lll}
\hline \multicolumn{1}{c}{ Sphincteristomum } & \multicolumn{1}{c}{ Sphincterostoma } & Postporus \\
\hline - The genus admits two species & - The genus admits two species & - The genus admits one species \\
- Tegument Smooth of body & - Tegument unarmed & - Tegument spinous \\
- The oral sucker is musculaire and large. & - Presence Very large lobed oral sucker.Sphincter & - oral sucker opening sbterminaly \\
- The ovary is transversally elongated, & surmounts the oral sucker. & - Absence of oral sphincter \\
- Two testes lobed heart-shaped. a bilateral & Ventral sucker much smaller than oral sucker. & - ventral sucker in anterior half of body \\
ondulating edge of the body and two terminal & - lateral and ovoid ovary & - Ovoid ovary \\
caeca open in ani. & - Testes two tandem & - Testes two or multiple \\
$\begin{array}{ll}\text { Caeca open via separate ani at posterior end of } \\
\text { body. }\end{array}$ & - The I-shaped excretory bladder is long and reaches & - Post acetabular terminal male genitalia. \\
$\begin{array}{ll}\text { Our species has an endothelial lining in caeca, at at } \\
\text { least in juvenile and ovigerous specimens }\end{array}$ & the anterior edge of the first testis. & - Very long I-shaped excretory bladder \\
& - No mention or drawing of endothelial lining in & - Caeca open to exterior through separate \\
& caeca of the two Sphincterostoma. caeca & uroproct, no endothelial lining.
\end{tabular}


Generic identification of our species. They appear very closely related of genus Sphincteristomum. And they display characteristics of a new species.

Specific identification of Sphincteristomum mediterraneae n.sp.

Specific name, $\boldsymbol{S}$. mediterraneae, because of its presence in the Mediterranean Sea.

Type locality. Oran bay, Algeria.

Host-type. Pagellus erythrinus, Sparidae.

Micro-habitat: intestine.

Holotype and paratype: samples $n^{\circ} 130$ TO2, 135 TO3.

Other samples n 127 TO1, 135 TO 4.

Name: Sphincteristomum mediterraneae Abid-Kachour, Mouffok and Boutiba.

\section{Discussion}

Geographic locations of Schistorchiinae and their final hosts.

Schistorchiinae subfamily sensu Cribb (2005) [1] contains few genera, described in several families of marine fishes spread all around the world. From East to West: Sea of Japan opening in North Pacific Ocean, Tonkin Bay on Sea of China, South Pacific Australian Ocean, Indian Asian Ocean, Indian African Ocean, Red Sea, Mediterranean (present result), and Atlantic American Ocean.

The genera of final hosts are enounced, as in authorsdescriptors. When it is possible, the family of fish is mentioned according to Tortonese (1973) [10].

Schistorchis carneus Lühe, 1906 from Tetrodon stellatus Tetraodontidae, near Sri Lanka, Indian Ocean. $\boldsymbol{S}$. haridis [11] from Pseudoscarus harid, Red Sea.

S. seychellesiensis Toman,1989, from Cantherines pardalis (Rupp, 1837), Indian Ocean. S. paruchini Kurochkin, 1974 from Navodon australis, South Pacific Ocean.

Megacreadium tetrodontis [12] from Tetrodon, in Red Sea.

Neomegacreadium okinawanum [6], from Triodontidae of Japanese and adjacent waters.

Sphincterostoma branchiostegi [5] from Branchiostegus japonicus in Sea of Japan. S. sp Manter, 1963 from a probable Balistapus Balistidae off Fiji.

Sphincteristomum acollum from Abalistes stellaris Balistidae in Tonkin Bay.

S. aniferum from triggerfish Balistidae from Fiji, in South Pacific Ocean.

S. mediterraneae n. sp. in Pagellus erythrinus Sparidae

Although the helminthofauna of Mediterranean is well known, since a long time, and although the Schistorchiinae display a visible feature, their large oral sucker including a sphincter, no mention of Sphincteristomum in Mediterranean fishes, or fishes from adjacent seas, is in reviews from Janiszewska (1953) [13,14], Papoutsoglou (1976) [15], Radujkovic et al. (1989a) [16], Radujkovic and Raibaut (1989b) [17], Bartoli et al. (2005) [18].

And no mention of dissections of Balistidae, generally, is in this Sea. Yet, according to Tortonese in Hureau and Monod (1973) [10] Balistidae live in Mediterranean, Adriatic, Black Sea, European North Atlantic Ocean from Madeira to United Kingdom, African South Atlantic Ocean, from Angola to Morocco.

Probably, in Mediterranean, Balistidae neither fished out, nor dissected, have unknown their Digenean fauna.

Life history of Sphincteristomum remains unknown. The stomach of our dissected $P$. erythrinus contained leftover of shrimps. It suggested that these arthropods be second hosts of Sphincteristomum and could content their larval stages.

Live span of $\boldsymbol{S}$. mediterraneae in $\boldsymbol{P}$. erythrinus. The simultaneous presence of juvenile, ovigerous and senile, Sphincteristomum in P. erythrinus the few number of eggs in the worms, seems to suggest a short life span of Sphincteristomum in Sparidae, an imperfect adaptation of these parasites towards this family-hosts. Is the seasonal large number of parasitized Pagellus, a sign of a quick spawn in hosts storages or shifts?

Relationships between Schistorchiinae, Apocreadiinae and Postporinae. Apocreadiinae and Postporinae have a typical oral sucker devoid of sphincter, devoid of lobe. They have two typical blind caeca, devoid of ani. Conversely, Schistorchiinae have a peculiar oral sphincter, an oral sucker either devoid of lobe or displaying lobes. They have caeca ending into two ani. Schistorchiinae appear more recent than Apocreadiinae and Postporinae.

\section{REFERENCES}

[1] T. H. Cribb, "Family Apocreadiidae Skrjabin," In: A. Jones, R. A. Bray and D. I. Gibson, Eds., Keys to the Trematoda, Vol. 2, CABI Publishing, Wallingford, 2005, pp. 621-639.

[2] S. Yamaguti, "Studies on Helminth Fauna of Japan. Part 39. Trematodes of Fishes Mainly from Naha," Transactions of the Biogeographical Society of Japan, Vol. 3, 1942, pp. 329-407.

[3] S. Yamaguti, "Systema Helminthum. The Digenetic Trematodes of Vertebrates, I," Interscience Publishing, London, 1958, pp. 950-979.

[4] P. G. Oshmarin, Y. Mamaev and A. M. Parukhin, "Two New Species and Genera of Trematodes of the Family Cryptogonimidae from Fishes of the North Viet-Nam (Tonking Bay)," Helminthologia, Vol. 3, 1961, pp. 261266.

[5] S. Yamaguti, "Studies on the Helminth Fauna of Japan. 17. Trematodes from a Marine Fish,” Branchiostegus Japonicus (Houttuyn), Kyoto, 1937, pp. 1-15.

[6] M. Machida and T. Kuramochi, "Digenean Trematodes 
from Japanese and Adjacent Waters,” Bulletin of the National Science Museum, Tokyo, Series A, Zoology, Vol. 25, No. 1, 1999, pp. 1-25.

[7] H. W. Manter, "The Digenetic Trematodes of Marine Fishes of Tortugas, Florida," American Midland Naturalists, Vol. 38, No. 2, 1947, pp. 257-416.

[8] H. W. Manter, "The Trematode Cathaemasia pulchroma (Travassos, 1916) n.comb. from the Body Cavity of a Kingfisher in Nebraska,” Journal of Parasitology, Vol. 35, No. 2, 1949 pp. 211-221. http://dx.doi.org/10.2307/3273139

[9] H. W. Manter, "Studies on Digenetic Trematodes of Fishes of Fiji. II Families Lepocreadiidae, Opistholebetidae and Opecoelidae," The Journal of Parasitology, Vol. 49, No. 1, 1963, pp. 99-113. http://dx.doi.org/10.2307/3275683

[10] E. Tortonese, “Catalogue des Poissons de l'Atlantique du Nord-Est et de la Méditerranée,” Unesco Paris, Vol. I, 1973, p. 683.

[11] H. T. Nagaty, "Trematodes of Fishes from the Red Sea Part 8. Five Species in the Families Schistorchidae, Acanthocolpidae, and Heterophidae,” Journal of Parasitology, Vol. 43, No. 2, 1957, pp. 217-220. http://dx.doi.org/10.2307/3274653

[12] H. T. Nagaty, "Trematodes of Fishes from the Red Sea
Part 7. On Two Gyliauchenids and Tree Allocreadoids, Including Four New Species,” Journal of Parasitology, Vol. 42, No. 5, 1956, pp. 523-527. http://dx.doi.org/10.2307/3274451

[13] J. Janiszewska, "Some Adriatic Sea Fish Trematodes. Zoologica Poloniae,” Archivum Societatis Zoologorum Poloniae, Vol. 6, No. 1, 1953, pp. 20-48.

[14] O. Sey, "Parasitic Helminths Occurring in Adriatic Fishes,” Acta Adriatica, Vol. 13, No. 6, 1970 pp. 1-16.

[15] S. S. Papoutsoglou, "Metazoan Parasites of Fishes from Saronicos Gulf. Athens, Greece,” Thalassographica, Vol. 1, No. 1, 1976, pp. 9-102.

[16] B. M. Radujkovic, P. Orecchia and L. Paggi, "Parasites des Poisons Marins du Montenegro: Digènes,” Acta Adriatica, Vol. 30, No. 1-2, 1989, pp. 137-187.

[17] B. M. Radujkovic and A. Raibaut, "Parasites des Poisons Marins du Montenegro: Liste des Espèces de Poissons Avec Leurs Parasites, ” Acta Adriatica, Vol. 30, No. 1-2, 1989, pp. 307-319.

[18] P. Bartoli, D. I. Gibson and R. A. Bray, "Digenean Species in Teleost Fish from a Nature Reserve off Corsica, France (Western Mediterranean) and a Comparison with Other Mediterranean Regions," Journal of Natural History, Vol. 39, No. 1, 2005, pp. 47-70. 